\title{
Breaking the silence: Advocacy and accountability for attacks on hospitals in armed conflict
}

\author{
Lara Hakki, Eric Stover and Rohini J. Haar* \\ Lara Hakki holds a JD from the University of California, \\ Berkeley (UC Berkeley) School of Law. She is a former clinical \\ intern at the International Human Rights Law Clinic at Berkeley.
}

Eric Stover is the Faculty Director of the Human Rights Center and Adjunct Professor of Law and Public Health at UC Berkeley.

Rohini J. Haar is a Lecturer in the School of Public Health and a Research Fellow at the Human Rights Center, UC Berkeley.

\begin{abstract}
When hospitals are damaged or destroyed in armed conflict, the loss is far greater than the physical structures: safe spaces are lost, health outcomes worsen and trust in health institutions is undermined. Despite the legal protections afforded to medical units under international humanitarian law (IHL), attacks on hospitals are a recurring problem in armed conflict. In 2019, the Safeguarding Health in Conflict Coalition documented more than 1,203 incidents of violence against medical facilities, transports, personnel and patients in twenty countries. This article examines investigations of four post-Second World War incidents of attacks
\end{abstract}

* The authors wish to acknowledge the research assistance provided by Burooj Mahmood and Andrew Mok, undergraduate students at the University of California, Berkeley. 
on hospitals in armed conflicts in Vietnam, Bosnia and Herzegovina, Palestine and Afghanistan, the role public advocacy campaigns played in bringing about these investigations, and how national and international authorities can work together to promote greater accountability for violations of IHL.

Keywords: international humanitarian law, laws of war, Geneva Conventions, attacks on hospitals, violence against health care, protection, medical neutrality, Vietnam, Bosnia, Palestine, Kunduz, Afghanistan, accountability, hospitals, armed conflict, war.

\section{Introduction}

Since the signing of the first Geneva Convention in 1864, a fundamental principle of international humanitarian law (IHL) has been that "[ $\mathrm{t}]$ he wounded and sick shall be collected and cared for". ${ }^{1}$ According to this principle, all wounded and sick persons, including civilians and wounded combatants who are considered hors de combat, are given a general protection. ${ }^{2}$ Geneva Convention IV (GC IV) on the protection of civilians, along with customary IHL, extends protection to civilian medical units where the wounded and sick are cared for, including hospitals. ${ }^{3}$ Any violation of this protection-including attacks "causing great suffering or serious injury to body or health" of persons who are protected under IHL, or leading to "extensive destruction and appropriation of property" that is likewise protected-will be considered a "grave breach" or a "war crime" and could potentially lead to individual criminal responsibility under international law. ${ }^{4}$

Despite this legal framework, countless attacks on hospitals in armed conflicts around the globe are met with impunity. In 2019 alone, there were at least 1,203 documented attacks in at least twenty countries. ${ }^{5}$ These attacks included direct violence in the form of bombings and raids, and the withholding of medical supplies. ${ }^{6}$ The vast majority of these attacks were not documented in a systematic manner, and few have been litigated in domestic or international criminal courts. Recent resolutions by the United Nations (UN) Security Council and General Assembly have reiterated the importance of protecting health-care

1 Art. 3 common to the four Geneva Conventions.

2 Jean-Marie Henckaerts and Louise Doswald-Beck (eds), Customary International Humanitarian Law, Vol. 1: Rules, Cambridge University Press, Cambridge, 2005 (ICRC Customary Law Study), Rule 110, available at: https://ihl-databases.icrc.org/customary-ihl/eng/docs/v1 (all internet references were accessed in August 2021).

3 Ibid.; Geneva Convention (IV) relative to the Protection of Civilian Persons in Time of War of 12 August 1949, 75 UNTS 287 (entered into force 21 October 1950), Art. 20.

4 GC IV, Art. 147. All four Geneva Conventions of 1949 and Additional Protocol I (AP I) of 1977 set out specific "grave breaches", or criminal violations, in relation to such attacks.

5 Safeguarding Health in Conflict Coalition, Health Workers at Risk: Violence against Health Care, 10 June 2020, available at: www.safeguardinghealth.org/sites/shcc/files/SHCC2020final.pdf.

$6 \quad$ Ibid. 
delivery during conflict and the need for systematic data collection and analysis to document those responsible for such attacks and their impact on civilian populations. ${ }^{7}$

Because legal rules are effective only if they can be enforced, the lack of accountability for these violations of IHL has led scholars to question the utility of the law. However, in this paper we argue that IHL has actually grown stronger in the past century and that the legal norms of IHL are now integrated into the domestic laws of more States than ever before. ${ }^{8}$ That said, what are missing in this paradigm are more frequent and thorough independent investigations and advocacy to ensure accountability of those responsible for ordering or carrying out attacks on hospitals.

In this article, we examine four attacks on hospitals and the extent to which measures were taken to investigate and prosecute those responsible. We chose to focus on hospitals rather than other categories of health-care services because hospitals are most frequently named and identifiable, and the destruction of infrastructure can result in long-term loss of health-care services for the surrounding community. The four incidents discussed in this article are those that occurred in Quynh Lap Hospital, Vietnam (1965); Koševo Hospital, Bosnia and Herzegovina (1992); Al-Shifa Hospital, Palestine (2014); and Kunduz Hospital, Afghanistan (2015). We selected these cases because they represent a broad geographic and chronological range, they took place during either a noninternational or international armed conflict where IHL applied, and they involved a public campaign to expose violations of IHL and/or were formally investigated by a court or other legal mechanism.

The authors wish to acknowledge that in each case study, the attacks were perpetrated by State parties, but in reality attacks on hospitals are frequently perpetrated by non-State groups. It is important to note that while IHL certainly applies to State actors, it would also apply if the perpetrator were a non-State actor through customary international law and Article 3 common to the four Geneva Conventions, and Additional Protocol II (AP II) where applicable. ${ }^{9}$ Additionally, medical units are protected in both international and noninternational armed conflicts, although the applicable legal rules differ slightly depending on the classification of the conflict. As noted below, the nuances of these legal rules are beyond the scope of this paper.

In each case study, we explored all publicly available literature, including legal documents and critiques, advocacy reports, news media and scholarly analysis. We also conducted open-ended interviews with jurists, military experts, researchers and investigators affiliated with international organizations. These interviews provided insights into the adequacy of legal responses taken in each of

7 UNSC Res. 2286, 3 May 2016.

8 International Committee of the Red Cross (ICRC), "Is the Law of Armed Conflict in Crisis and How to Recommit to Its Respect?", panel at the Conference on "Generating Respect for the Law", 26 April 2016, available at: www.icrc.org/en/event/law-armed-conflict-crisis-and-how-recommit-its-respect.

9 Waseem Ahmad Qureshi, “Applicability of International Humanitarian Law to Non-State Actors”, Santa Clara Journal of International Law, Vol. 17, No. 1, 2019, p. 10. 
the cases. Our aim was to gain a historical perspective on how legal investigations of these attacks were initiated and conducted, as well as the degree to which the investigations promoted accountability. We also sought to understand whether public campaigns calling for accountability for such attacks promoted more robust investigatory responses from institutions mandated to enforce IHL. We chose to focus on cases where criminal accountability was pursued, but wish to recognize that investigations into attacks may also pursue other purposes, such as developing guidelines and procedures for the systematic documentation of attacks on hospitals.

Our case studies reveal three pressing needs that the international community should address in order to promote greater adherence to IHL. First, to promote accountability, national and international investigations into attacks on hospitals and other violations of IHL must be conducted in an independent, robust and transparent manner. Second, there is a need for greater civil society engagement and publicity to press for investigations into violations of IHL. Without public awareness or calls for investigations by both local and international organizations, accountability is far less likely to occur. For example, with the advance of mobile technologies and social media, a growing number of civil society organizations have begun conducting investigations using publicly available online data in an effort to document and publicize attacks on hospitals in armed conflict. Finally, where possible, international or national actors should pursue criminal prosecutions for such attacks.

\section{Applicable law}

What follows is an overview of the protection afforded to hospitals under IHL. The authors wish to note that this section provides only a high-level overview of the applicable law, since this article focuses on an analysis of four historical case studies. Other scholars have undertaken a deeper analysis of IHL and international human rights law issues surrounding hospitals, other health-care facilities, and health-care personnel. ${ }^{10}$

As mentioned above, medical units such as hospitals are afforded protection under IHL; however, this protection is not absolute. ${ }^{11}$ When hospitals are used outside of a humanitarian function, their protection may be lost. ${ }^{12}$ For example, if hospitals are "used to commit, outside their humanitarian duties, acts harmful to the enemy", then attacks against them are not expressly

10 See Alexander Breitegger, "The Legal Framework Applicable to Insecurity and Violence Affecting the Delivery of Health Care in Armed Conflicts and Other Emergencies", International Review of the Red Cross, Vol. 95, No. 889, 2014.

11 Alma Baccino-Astrada, Manual on the Rights and Duties of Medical Personnel in Armed Conflicts, ICRC and League of Red Cross and Red Crescent Societies, Geneva, 1982, p. 32.

12 ICRC, Commentary on the First Geneva Convention: Convention (I) for the Amelioration of the Condition of the Wounded and Sick in Armed Forces in the Field, 2nd ed., Geneva, 2016 (ICRC Commentary on GC I), Art. 21, para. 1842, available at: https://tinyurl.com/25cb6v2p. 
prohibited, so long as the attacks also conform to the rules on proportionality and precaution. ${ }^{13}$ While other scholarly articles more thoroughly explore the notion of "acts harmful to the enemy" under IHL, ${ }^{14}$ this paper does not explore the legal notion fully. It is sufficient to understand that hospital misuse-such as using a hospital to gain a military advantage or to shield military objectives from attack removes the protection for hospitals under IHL. Article 19 of GC IV states that hospitals shall not lose their protections under IHL "unless they are used to commit, outside their humanitarian duties, acts harmful to the enemy". Examples of such acts include "the use of a hospital as a shelter for able-bodied combatants or fugitives, as an arms or ammunition store, as a military observation post, or as a centre for liaison with fighting troops". These transgressions can lead to the withdrawal of protection. ${ }^{15}$

Under IHL, "attacks" are defined as "acts of violence against the adversary, whether in offence or in defence". ${ }^{16}$ All parties to an armed conflict have a legal duty to "respect and ensure respect for" IHL. ${ }^{17}$ While the laws proscribing attacks on hospitals are clearly defined in IHL, the mechanisms and protocols for investigating alleged attacks are less clear. The duty to respond to alleged violations of IHL can come from various sources, including human rights law, international criminal law, laws governing States' responsibilities, and IHL itself. This paper focuses on the duty to examine and investigate under IHL, since the incidents we examine took place in situations of armed conflict where IHL is considered lex specialis - the law governing a specific subject matter. ${ }^{18}$

The scope of this duty is important - the duty to examine and investigate is only triggered when there is an alleged violation that could rise to the level of a "grave breach" of IHL or a war crime. ${ }^{19}$ However, some attacks on civilians or

13 GC IV, Art. 19; Protocol Additional (II) to the Geneva Conventions of 12 August 1949, and relating to the Protection of Victims of Non-International Armed Conflicts, 1125 UNTS 609, 8 June 1977 (entered into force 7 December 1978) (AP II), Arts 9-11, 13; ICRC Customary Law Study, above note 2, Rules 25-29; Dustin A. Lewis, Naz K. Modirzadeh and Gabriella Blum, Medical Care in Armed Conflict: International Humanitarian Law and State Responses to Terrorism, Harvard Law School Program on International Law and Armed Conflict, 8 September 2015, p. 5.

14 See Robert Kolb and Fumiko Nakashima, "The Notion of 'Acts Harmful to the Enemy' under International Humanitarian Law", International Review of the Red Cross, Vol. 101, No. 912, 2019.

15 Jean Pictet (ed.), Commentary on the Geneva Conventions of 12 August 1949, Vol. 4: Geneva Convention (IV) relative to the Protection of Civilian Persons in Time of War, ICRC, Geneva, 1958, Art. 19, pp. 154, 200. See also ICRC, Basic Rules of the Geneva Conventions and Their Additional Protocols, Geneva, 1988, available at: www.icrc.org/en/publication/0365-basic-rules-geneva-conventions-and-their-additionalprotocols; R. Kolb and F. Nakashima, above note 14.

16 Protocol Additional (I) to the Geneva Conventions of 12 August 1949, and relating to the Protection of Victims of International Armed Conflicts, 1125 UNTS 3, 8 June 1977 (entered into force 7 December 1978) (AP I), Art. 49(1).

17 Art. 1 common to the four Geneva Conventions.

18 A. Breitegger, above note 10; ICRC, "Glossary: Lex Specialis", How Does Law Protect in War?, available at: https://casebook.icrc.org/glossary/lex-specialis.

19 In contemporary international law, "grave breaches" only apply to international armed conflict, but war crimes can be committed in both international and non-international armed conflicts. Geneva Convention (I) for the Amelioration of the Condition of the Wounded and Sick in Armed Forces in the Field of 12 August 1949, 75 UNTS 31 (entered into force 21 October 1950) (GC I), Art. 49; ICRC Customary Law Study, above note 2, Rule 158: States must investigate war crimes allegedly committed by their nationals or armed forces, or on their territory, and if appropriate, prosecute the suspects. 
civilian objects, even if they result in death or injury, may nevertheless be lawful under IHL. For example, if a hospital were in fact to be misused, an attack on that hospital would not necessarily rise to the level of a war crime and would not need to be investigated. ${ }^{20}$ Nevertheless, the attacker must still prove that the hospital was misused, presumably through an investigation. ${ }^{21}$ Furthermore, in case of doubt, there should be a presumption of civilian status. ${ }^{22}$

Although the duty to investigate is clear, the law does not require States to investigate alleged war crimes, and nor does it specify exactly how they should do so. For example, Article 90 of Additional Protocol I (AP I) provides for the establishment of an international fact-finding commission (called the International Humanitarian Fact-Finding Commission, or IHFFC), which could "inquire into any facts alleged to be a grave breach" of the Geneva Conventions. $^{23}$ State Party adherence to Article 90 means recognizing the competence of the IHFFC to investigate allegations by another party. However, State Party adherence to Article 90 is optional: out of the 179 States that have signed AP I, only seventy-seven have made a declaration accepting the IHFFC's competence to investigate alleged breaches. ${ }^{24}$ More recently, in May 2016, the UN Security Council adopted Resolution 2286, which condemns attacks on hospitals and

strongly urges States to conduct, in an independent manner, full, prompt, impartial and effective investigations within their jurisdiction of violations of International Humanitarian Law related to the protection of the wounded and sick, medical personnel and humanitarian personnel exclusively engaged in medical duties. ${ }^{25}$

However, the Syrian American Medical Society (SAMS) and other organizations have questioned the usefulness of this resolution, which has no legal power to require such investigations. ${ }^{26}$ In fact, after Resolution 2286 was passed, SAMS reported that the rate of attacks on hospitals and health workers in Syria increased by $89 \% .^{27}$

20 Public Commission to Examine the Maritime Incident of 31 May 2010 (Turkel Commission), Israel's Mechanisms for Examining and Investigating Complaints and Claims of Violations of the Laws of Armed Conflict According to International Law, Second Report, February 2013, p. 102, available at: www.hamoked.org/files/2013/1157610_eng.pdf; GC IV, Art. 146.

21 AP I, Art. 52(2). A belligerent has the burden of establishing in a definite manner that an armed attack was launched against it by a specific attacker and that its response was necessitated as a matter of last resort. It also must establish that its targets are lawful. See, for example, International Court of Justice, Oil Platforms (Islamic Republic of Iran v. United States of America), Judgment, 6 November 2003, ICJ Reports 90, para. 51.

22 AP I, Art. 52(3).

23 Ibid., Art. 90: “An International Fact-Finding Commission ... consisting of fifteen members of high moral standing and acknowledged impartiality shall be established to inquire into any facts alleged to be a grave breach as defined in the 1949 Geneva Conventions and AP I or other serious violation of the 1949 Geneva Conventions or of AP I."

24 Ibid.

25 UNSC Res. 2286, 3 May 2016.

26 SAMS, The Failure of UN Security Council Resolution 2286 in Preventing Attacks on Healthcare in Syria, 11 January 2017, available at: www.sams-usa.net/wp-content/uploads/2017/03/UN-fail-report-07-3.pdf.

27 Ibid. 
With this understanding of the key legal obligations involved, we now examine four cases that illustrate how States have investigated alleged attacks on hospitals over the past five decades.

\section{Case studies: Vietnam, Bosnia and Herzegovina, Palestine and Afghanistan}

In each case study, we examine the context of the attack; international reactions including publicity campaigns - to the attack; what formal investigation(s), if any, were carried out; and the outcomes. We include details from the literature review and insights from our key informant interviews where possible, and conclude with a critical review of the findings and their impact on IHL.

\section{Quynh Lap Hospital, Vietnam}

During the Vietnam War, the United States conducted widespread attacks in populated areas, which in some cases hit civilian infrastructure and hospitals. ${ }^{28}$ These attacks were part of a broader strategy to erode civilian order and the morale of the North Vietnamese army. ${ }^{29}$ Declassified US Air Force manuals that were released after the Vietnam War show that hospitals, schools and churches were listed as "psycho-social targets". ${ }^{30}$ A former US Army intelligence specialist explained that hospitals were rated highly as strategic targets because they were often protected by company- or battalion-sized troop units. So "the bigger the hospital" - i.e., the higher the military gain - "the better it was to attack". ${ }^{31}$

One such attack took place on the night of 12 June 1965, when US planes bombed the Quynh Lap leprosarium, the largest centre for the research and treatment of leprosy in the Democratic Republic of Vietnam (DRV), constructed on an isolated island far removed from other civilians and industrial centres. The entire health-care complex consisted of 160 buildings and treated as many as 2,600 patients at any given time. ${ }^{32}$ The complex was well recognized by the international community as a health-care facility and was prominently marked with the red cross emblem, the international emblem of health services. ${ }^{33}$

After the initial attack on 12 June, the health workers did not immediately evacuate the patients since they believed the attack must have been a mistake and that US forces would soon realize they had attacked a health-care

28 John Duffett and Bertrand Russell, Against the Crime of Silence: Proceedings of the Russell International War Crimes Tribunal, Bertrand Russell Peace Foundation, London, 1967, p. 181.

29 Marvin E. Gettleman et al., Vietnam and America: A Documented History, Grove Press, New York, 1995, p. 464.

30 Ibid.

31 Greg Grandin, "In Vietnam War US Deliberately Bombed Hospitals", History News Network, 5 October 2015, available at: https://historynewsnetwork.org/article/160863.

32 Peter Limqueco, Peter Weiss and Ken Coates, Prevent the Crime of Silence, Allen Lane, London, 1971, p. 98.

33 J. Duffett and B. Russell, above note 28, p. 181. 
facility. ${ }^{34}$ However, over the next ten days, US forces continued to attack the leprosarium with rockets, machine guns and cannon fire. ${ }^{35}$ The US air raids destroyed approximately one third of the buildings in the health-care complex. ${ }^{36}$

The patients at Quynh Lap were forced to evacuate to caves located 6 kilometres from the leprosarium. The attacks killed 139 patients and nine medical personnel, wounded approximately 1,000 people, and deprived more than 2,000 patients of medical care. ${ }^{37}$ Further investigations also found white phosphorous, a deadly chemical historically utilized as a weapon and sometimes as a smokescreen, at the site. ${ }^{38}$

\section{Investigations and outcomes}

On 14 July 1965, the DRV Ministry of Public Health issued a public statement denouncing these attacks on a clearly defined health-care facility that bore the red cross symbol. ${ }^{39}$ A week later, the president of the Red Cross Society of the DRV, $\mathrm{Vu}$ Dinh Tung, sent a letter to the president of the International Committee of the Red Cross (ICRC), Samuel Alexandre Gonard, claiming that the United States had violated IHL by bombing hospitals and using chemical weapons. The letter referred specifically to the attacks on the Quynh Lap leprosarium as "grave crimes". ${ }^{40}$ The letter also described the attacks as deliberate and insisted that they could not have been part of any military objective, since "the [Johnson government] cannot claim there was any confusion that our hospitals clearly carried the symbol of the Red Cross on their doors or on their roofs" ${ }^{41}$ Since the United States had signed and ratified GC IV, which designates civilian hospitals as objects benefiting from special protection, ${ }^{42}$ Tung urged the ICRC to address these violations. Despite the outcry, US planes returned on 22 July and attacked new buildings in the Quynh Lap health-care complex, killing thirty-four and wounding thirty more individuals. ${ }^{43}$

In response to the earlier letter, the US Mission to International Organizations sent a letter on 24 September 1965 to Gonard denying the allegations that US aircraft had bombed medical facilities in Vietnam or employed toxic chemical products. ${ }^{44}$ The letter indicated that a "most careful investigation by the United States Government indicates that United States aircraft attacked no targets we could identify as medical facilities". ${ }^{45}$ However, the

37 P. Limqueco, P. Weiss and K. Coates, above note 32, p. 159.

38 Ibid.

39 Ibid., p. 159.

40 Letter from Vu Dinh Tung to Samuel Alexandre Gonard, 21 July 1965.

41 Ibid.

42 GC IV, Art. 18.

43 John Gerassi and Conor Cruise, North Vietnam: A Documentary, George Allen and Unwin, London, 1968, p. 99; GC IV, Art. 18.

44 Letter from US Mission to International Organizations to Samuel Alexandre Gonard, 24 September 1965. 45 Ibid. 
letter did not describe how this investigation had been conducted, or by whom. ${ }^{46}$ Moreover, the letter justified the attacks by stating that the locations mentioned including Quynh Lap - had been "identified from a variety of military intelligence sources as the location of military installations". ${ }^{47}$ The letter also claimed that the US government had photographs showing that the "medical installations were not marked by distinctive Red Cross emblems clearly visible from the air as required by the Geneva Conventions and that they were placed in close proximity to military targets in violation of the conventions". ${ }^{48}$ The letter urged the ICRC to conduct an on-the-ground investigation to examine whether "all medical facilities were properly marked and verified, and that such facilities were not located with military establishments". ${ }^{9}$ The results of this investigation were not publicly available at that time.

In 1966, British philosopher and Nobel Prize winner Bertrand Russell organized a private independent tribunal to investigate and evaluate US foreign policy and military intervention in Vietnam. The commission, called the Russell Tribunal, also included French philosopher and writer Jean-Paul Sartre and was conducted in two sessions. The Russell Tribunal's final report described the bombing of the leprosarium at Quynh Lap and concluded that attacks on DRV health-care facilities amounted to "U.S imperialist aggression in Vietnam [that] breaks all rules of health recognized by the world". ${ }^{50}$ While the Russell Tribunal brought international attention to the conflict, it had no legal authority to determine individual liability, and was largely ignored by the US authorities. Because the Tribunal was not a government body or a treaty organization, it had neither the legal authority nor the means to carry out a formal investigation, let alone render a verdict. ${ }^{51}$

After the Vietnam War officially ended in 1973, the Senate Armed Services Committee established a commission to investigate the conduct of the air war in Vietnam. Another former US Army intelligence specialist, Alan Stevenson, testified that he had routinely listed hospitals as targets during the war. ${ }^{52}$ In fact, as mentioned above, the classified US Air Force bombing manual defined hospitals, schools and churches as "psycho-social targets" useful for the destruction of civilian order and morale. ${ }^{53}$ Despite this testimony, the commission did not extrapolate intention on the part of the US forces to

46 Ibid.

47 Ibid.

48 Ibid.

49 Ibid.

50 J. Duffett and B. Russell, above note 28, p. 181.

51 US Senate, “About Investigations", available at: www.senate.gov/about/powers-procedures/investigations. htm. The authority of Congress to investigate is an implied constitutional power. Since its earliest investigations, Congress has availed itself of the power of inquiry in order to inform the public and to write good legislation. Courts in the United States have broadly construed congressional powers to conduct investigations. See also Cody J. Foster, "Did America Commit War Crimes in Vietnam?", New York Times, 1 December 2017, available at: www.nytimes.com/2017/12/01/opinion/did-americacommit-war-crimes-in-vietnam.html.

52 G. Grandin, above note 31.

53 M. E. Gettleman et al., above note 29, p. 464. 
deliberately target hospitals. The commission thus did not result in any prosecutions or convictions directly related to aerial attacks on health care.

\section{Discussion}

While it is clear that US air raids in Vietnam resulted in attacks on hospitals and, subsequently, some attempts at a public trial, there was no overwhelming public outcry or awareness about these specific attacks. The North Vietnamese Red Cross attempted to raise awareness of these attacks, but the statements and correspondence were not made public at the time. ${ }^{54}$ The correspondence illustrates an important awareness and recognition by both the United States and the DRV of the alleged IHL violations, but despite this awareness, neither party conducted formal independent investigations.

The Vietnam War marked an important historical turning point where civil society began to question State actions during wartime and demand impartial information. Developments in photographic journalism helped civil society groups investigate and document later situations of armed conflict. ${ }^{55}$ Although there is no question that civil society became emboldened after Vietnam to call for investigations and State accountability for alleged violations of the law in war, this case study suggests that even with publicity campaigns, general public awareness of violations of IHL is limited and future campaigns may be more successful if they directly advocate for formal investigations.

Formal governmental engagement and independent investigations are critical to acknowledging these incidents and holding perpetrators accountable. The Quynh Lap Hospital case study illustrates the importance of independent and transparent investigations for all alleged violations of IHL. Although the US Mission to International Organizations claimed it had conducted a "most careful investigation", the US government did not indicate how it reached the conclusion that none of the air strike targets were identifiable as medical facilities. ${ }^{56}$ The authors acknowledge that the means of verifying lawful military targets have become more sophisticated since the Vietnam War and that the lack of a robust investigation into these attacks may have been due in part to the lack of evidence available at the time. Even so, accountability mechanisms in this case were inadequate. While the Senate investigation raised public awareness about US attacks on health-care facilities, it was not conducted in a systematic process. And while the Russell Tribunal attempted to promote awareness, ${ }^{57}$ it lacked legal authority and resources and, in our view, may have even undermined efforts to press for a more formal accountability mechanism.

54 These letters are now publicly available in the ICRC archives at: www.icrc.org/en/archives.

55 Susan D. Moeller, Shooting War: Photography and the American Experience of Combat, Basic Books, New York, 1989.

56 Ibid.

57 Marcos Zunino, "Subversive Justice: The Russell Vietnam War Crimes Tribunal and Transitional Justice", International Journal of Transitional Justice, Vol. 10, No. 2, 2016. 


\section{Koševo Hospital, Bosnia and Herzegovina}

Ethnic tensions in the Republic of Bosnia and Herzegovina came to a head after the country declared independence in 1992. Serb nationalists, who opposed independence, formed the Army of the Republika Srpska (Vojske Republike Srpske, VRS) and attacked Bosnian Muslim and Croat enclaves inside the capital city of Sarajevo in April 1992, beginning what came to be known as the Siege of Sarajevo. ${ }^{58}$ The VRS encircled most of the city, blocking humanitarian aid, including food, water, electricity, heating fuel and medicine, and targeted civilian sites, including homes, schools and medical complexes. ${ }^{59}$ Reports indicate that over the course of the four-year siege, the VRS carried out an average of 329 distinct attacks each day on the city, using snipers, artillery, tanks and small arms. ${ }^{60}$ The siege officially ended in December 1995 when NATO forces brokered a peace agreement.

Between 1992 and 1995, the VRS repeatedly shelled Koševo Hospital, the main medical facility in Sarajevo (which still functions today). ${ }^{61}$ By early 1993 , the hospital had been shelled a total of 172 times. $^{62}$ A UN commission tasked with investigating violations of IHL in the Balkan conflict reported in 1994 that "as the hospital is clearly visible from Bosnian Serb positions, at least some of those impacts must be considered intentional". ${ }^{63}$

According to Asim Haračić, a surgical resident at Koševo during the siege, the hospital's trauma unit, located on the third floor of the hospital, served as many as fifty to 100 wounded civilians a day, most of whom were suffering from burn injuries and gunshot wounds. ${ }^{64}$ Dr Haračić recalled that during the worst times of the conflict, when there was no ceasefire, ten to fifteen patients would die each day as a direct result of attacks. On several occasions, the hospital was forced to close or move some of its surgical team underground to avoid the shelling. ${ }^{65}$ One of the most flagrant military attacks on the Koševo Hospital clinic complex took place in May 1992, when Bosnian Serb forces repeatedly shelled the children's clinic at close range from their position 50 metres from the clinic. ${ }^{66}$

58 Sylvia Poggioli, “Two Decades after Siege, Sarajevo Still a City Divided”, National Public Radio, 5 April 2012, available at: www.npr.org/2012/04/05/150009152/two-decades-after-siege-sarajevo-still-a-citydivided. See also "Balkans War: A Brief Guide", BBC News, 18 March 2016, available at: www.bbc. com/news/world-europe-17632399.

59 International Criminal Tribunal for the former Yugoslavia (ICTY), Prosecutor v. Galić, Case No. IT-98-29T, Indictment, 26 March 1999, p. 2, available at: www.icty.org/x/cases/galic/ind/en/gal-ii990326e.pdf.

60 Ibid., p. 1.

61 Physicians for Human Rights, Medicine under Siege in the Former Yugoslavia: 1991-1995, May 1996, p. 82.

62 Ibid.

63 UN Commission on Human Rights, Situation of Human Rights in the Territory of the Former Yugoslavia: Fifth Periodic Report, UN Doc. E/CN.4/1994/47, 17 November 1993, available at: https://digitallibrary.un. org/record/176946? ln=en.

64 Telephone interview with Asim Haračić, November 2018.

65 Ibid.

66 Ibid. 


\section{Investigations and outcomes}

In March 1992, the UN dispatched peacekeeping forces with the hope of discouraging future attacks by Serbian forces. ${ }^{67}$ However, the UN could not protect its own vehicles or supplies and was forced to evacuate the city in May $1992 .{ }^{68}$ While the peacekeepers were seen as ineffective, the UN did establish a commission of experts to investigate and collect evidence of "grave breaches of the Geneva Conventions and other violations of humanitarian law". 69 The commission collected evidence from news agencies and human rights organizations, including Physicians for Human Rights. Following the commission's First Interim Report at the end of 1992, the UN Security Council established the International Criminal Tribunal for the former Yugoslavia (ICTY) to investigate and prosecute war crimes and other serious crimes in the former Yugoslavia. ${ }^{70}$ Six years later, the ICTY charged General Stanislav Galić, the commander of the VRS Sarajevo-Romanija Corps, with the war crime of terrorizing a civilian population. ${ }^{71}$ Critically, the ICTY's chief prosecutor did not bring a separate charge for the crime of attacking a medical facility.

The defence claimed that civilian losses were "unavoidable" and "collateral to legitimate military actions". ${ }^{72}$ In particular, Galić asserted that he never ordered the direct shelling of Koševo Hospital, only the surrounding area, and only "as a response to ... military activities from that area", which made it a legitimate military target. ${ }^{73}$ The Trial Chamber dismissed these claims. It concluded that only a small fraction of the incidents could have been accidents and added that the attacks had "no discernable significance in military terms". ${ }^{74}$ It based this finding on ten witness testimonies and a number of UN reports testifying to thirteen specific attacks on the hospital, acknowledging that there were "numerous other times" between 1992 and 1995 that the hospital or its grounds had been shelled. ${ }^{75}$ However, the Trial Chamber did find evidence that mortar fire had come from "the hospital grounds or its vicinity" ${ }^{76}$ Later the Appeals Chamber held that at least some of the attacks were justified where the hospital had been used "as a base from which to fire at Galić's forces". The Chamber concluded that this "fire from the hospital turned it into a target" but clarified that this type of misuse did not turn a protected facility into a permanent

67 Physicians for Human Rights, above note 61, p. 18.

68 Ibid., p. 18.

69 UNSC Res. 780, 6 October 1992.

70 UNSC Res. 808, 22 February 1993.

71 ICTY, Galić, above note 59. The ICTY charged the crime of terrorizing the civilian population on the basis of Article 51(2) of AP I and Article 13(2) of AP II, both of which state that "the civilian population as such, as well as individual civilians, shall not be the object of attack. Acts or threats of violence, the primary purpose of which is to spread terror among the civilian population, are prohibited."

72 ICTY, Prosecutor v. Galić, Case No. IT-98-29-T, Summary of Judgment (Trial Chamber), 5 December 2003, available at: www.icty.org/x/cases/galic/tjug/en/031205_Gali_summary_en.pdf.

73 Ibid.

74 Ibid.

75 Ibid.

76 Ibid. 
military target - rather, the hospital remained a legitimate target "only as long as it [was] reasonably necessary for the opposing side to respond to the military activity". ${ }^{77}$ The Appeals Chamber judgment also articulated conditions that do not deprive medical units of their special protected status, including if they are used to treat sick and wounded combatants and if arms are present inside the units. $^{78}$

On 5 December 2003, the ICTY convicted Stanislav Galić of ordering "attacks on civilians and acts of violence with the primary aim of spreading terror among the civilian population" under Article 3 of the ICTY Statute. ${ }^{79}$ Galić was sentenced to life imprisonment. However, the ICTY Trial Chamber did not pursue further prosecutions associated with attacks on hospitals during the siege, and no separate charge for the crime of attacking a medical unit was ever brought. While this may have been a decision based on prosecutorial discretion, it reflects a missed opportunity to underscore the importance of protecting hospitals.

\section{Discussion}

While the Galić conviction was one of the few made by an international tribunal for violations of IHL, the verdict made only passing reference to attacks on Koševo Hospital during the Siege of Sarajevo. Instead, the ICTY considered the attacks as part of the broader campaign of terrorizing the civilian population, not separately as an attack on "an object enjoying special protection under IHL". ${ }^{80}$ It is not clear why the ICTY did not pursue a separate prosecution for the attacks on Koševo Hospital. Perhaps this decision was in part due to the fact that the Tribunal could not establish that the hospital was never misused, since at one point, mortar fire did come from "the hospital grounds or its vicinity". ${ }^{81}$ The Appeals Chamber considered a variety of sources, including eyewitness reports from UN military observers, and did conclude that while the hospital was at times misused, some of the attacks on the hospital were illegitimate attacks on civilians. $^{82}$ A prosecution for targeting the hospital would have to address the timing of the misuse and the attacks, and make a determination about when exactly the hospital regained its special protected status, which may have been difficult. Perhaps the ICTY did not want to separate and classify attacks on hospitals from generally protected civilian objects. Perhaps, also, the prosecutors chose to include this attack in the broader charge of "terrorizing a civilian population" which addressed the full extent of violence against civilians.

77 ICTY, Prosecutor v. Galić, Case No. IT-98-29-T, Judgment (Appeals Chamber), 30 November 2006, p. 154, available at: www.icty.org/x/cases/galic/acjug/en/gal-acjud061130.pdf.

78 Ibid., p. 147.

79 Natalino Ronzitti, "Protected Areas", in Andrew Clapham, Paola Gaeta and Marco Sassòli (eds), The 1949 Geneva Conventions: A Commentary, Oxford University Press, Oxford, 2015, p. 385.

80 Elżbieta Mikos-Skuza, "Hospitals", in A. Clapham, P. Gaeta and M. Sassòli (eds), above note 79, p. 227.

81 Ibid.

82 ICTY, Galić, above note 77, p. 150. 
Nevertheless, the Galić conviction fell short of sending a strong signal about the special protected status of hospitals. As the prosecution argued, the deliberate assaults on medical care and facilities should be considered as violations of the laws of the war and should be prosecuted alongside murder and other crimes. ${ }^{83}$ While Galić was not charged specifically for his attacks on Koševo Hospital, the Tribunal did advance the law protecting hospitals by clarifying the types of hospital misuse that can and cannot justify attacks. ${ }^{84}$ It also reinforced the legal rule that one instance of hospital misuse does not justify making a hospital a permanent military target.

The Galić case illustrates how UN commissions, working with international human rights organizations, can document attacks on hospitals and bring these violations to the attention of judicial authorities. The case also reveals how investigations into violations of IHL became more impartial and transparent as tribunals, such as the ICTY, were established. Additionally, the Galić trial is important because it was one of the few successful prosecutions by an international tribunal for war crimes related to attacks against hospitals. Though it did not bring direct accountability for attacking health care, the Appeals Chamber's decision clarified the notion of hospital misuse and reinforced the gravity of such a crime. These outcomes support the importance of criminal accountability for violations of IHL.

\section{Al-Shifa Hospital, Palestine}

After Hamas, a Palestinian Sunni-Islamic organization, won the Palestinian legislative election in 2007, Israel, in an attempt to crack down on what it considered a terrorist group, began a blockade of the Gaza Strip, which undermined the local economy and severely restricted the rights of Palestinians. ${ }^{85}$ In the summer of 2014, widespread protests and violent clashes ensued between organized armed groups based in the Gaza Strip and the Israeli Defense Forces (IDF). ${ }^{86}$ Palestinian forces launched rockets into Israel in June and July 2014, and IDF forces retaliated by launching Operation Protective Edge on 7 July 2014. The IDF's stated objective was to attack Hamas and destroy its military capabilities. The hostilities lasted fifty-one days, resulting in more than a thousand deaths and widespread destruction of the Gaza Strip. ${ }^{87}$

On 28 July 2014, Israeli forces bombed Al-Shifa Hospital, the main referral hospital for the Gaza Strip. At the time of the attack, a surgical team with Doctors Without Borders (Médecins Sans Frontières, MSF) was working in the hospital.

83 ICTY, Prosecutor v. Galić, Case No. IT-98-29-PT, Prosecution Pre-Trial Brief, 23 October 2001, available at: www.icty.org/x/cases/galic/pros/en/011023.pdf.

84 E. Mikos-Skuza, above note 80, p. 227.

85 Human Rights Council, Report of the Independent Commission of Inquiry on the 2014 Gaza Conflict, UN Doc. A/HRC/29/52, 24 June 2015, p. 5.

86 Ibid.

87 "UN Report Cites Possible War Crimes by both Israel and Palestinian Groups in 2014 Gaza Conflict", UN News, 22 June 2015, available at: https://news.un.org/en/story/2015/06/502282-un-report-cites-possiblewar-crimes-both-israel-and-palestinian-groups-2014. 
Shortly afterwards, MSF condemned the attack, calling it "completely unacceptable and a serious violation of International Humanitarian Law". ${ }^{88}$ The MSF head of mission in the Occupied Palestinian Territories stated that "[w]hatever the circumstances, health facilities and medical staff must be protected and respected. But in Gaza today, hospitals are not the safe havens they should be." 89

The IDF also bombed three other hospitals in Gaza: the European General Hospital, Beit Hanoun Hospital and Al-Aqsa Hospital, a 190-bed government hospital that was treating civilians who had sought safety inside the facility. ${ }^{90}$ Israel justified these attacks, specifically its attack on Al-Shifa Hospital, by claiming that Hamas had established a "large underground bunker equipped with sophisticated communications equipment" underneath the hospital, ${ }^{91}$ which would qualify as an "act harmful to the enemy". The same day, one hour after Al-Shifa was attacked, another strike landed near the hospital and hit Al-Shati refugee camp. This strike killed ten Palestinians, nine of them children. ${ }^{92}$ Israel denied responsibility for the attack and instead blamed the attack on Hamas. The IDF later released a statement saying:

Al-Shifa hospital was struck by a failed rocket attack launched by Gaza terror organizations. A barrage of three rockets that were aimed towards Israel, struck the hospital. At the time of the incident there was no Israeli military activity in the area surrounding the hospital whatsoever..$^{93}$

That same day, the official IDF Twitter account stated: "A short while ago, terrorists in Gaza fired rockets at Israel. 1 of them hit Al-Shifa Hospital in Gaza. The other hit Al-Shati refugee camp." 94 These conflicting reports, first justifying and then denying the attacks, were never properly investigated.

\section{Investigations and outcomes}

Following the conflict in the summer of 2014, then UN Secretary-General Ban KiMoon criticized the "low rate of investigations" into the alleged violations of IHL in the Gaza Strip..$^{95}$ Various human rights groups in Israel, including B’Tselem, have

88 MSF, “Gaza: MSF Strongly Condemns Attack on Al Shifa Hospital”, 29 July 2014, available at: https:// doctorswithoutborders.org/what-we-do/news-stories/news/gaza-msf-strongly-condemns-attack-al-shifahospital.

89 Ibid.

90 Julie Webb-Pullman et al., "Attack on a Hospital in the Gaza Strip: A Descriptive Study”, The Lancet, Vol. 391, Special Issue 1, 21 February 2018.

91 Lucy Westcott, "Who Fired on Gaza's Shifa Hospital?", Newsweek, 30 July 2014, available at: www. newsweek.com/mysterious-case-gazas-al-shifa-hospital-262086.

92 Kia Makarechi, “Who's Responsible for Bombing Near Gaza's Al-Shifa Hospital?”, Vanity Fair, 28 July 2014, available at: www.vanityfair.com/news/politics/2014/07/gaza-shifa-hospital-bombing.

93 L. Westcott, above note 91.

94 Israeli Defense Forces (@IDF), Twitter, 28 July 2014, 10:56 AM, available at: https://twitter.com/IDF/ status/493787191621849088.

95 UN, "UN Note to Correspondents in Response to a Question Raised at the Noon Briefing on the Israeli Investigations into Events in Gaza in 2014", 25 August 2016, available at: www.un.org/sg/en/content/sg/ note-correspondents/2016-08-25/note-correspondents-response-question-raised-noon-briefing. 
criticized the inadequacy of Israeli military investigations. ${ }^{96}$ A year later, the Office of the United Nations High Commissioner for Human Rights set up an Independent Commission of Inquiry to investigate whether war crimes had been committed in Gaza. Israel did not cooperate with the Commission or allow the UN to conduct investigations in Israel or the Gaza Strip. As a result, the Commission had to base its report on written testimony and hundreds of witness interviews conducted remotely. The Commission's report, released in June 2015, found evidence that both parties to the conflict may have committed war crimes. ${ }^{97}$

The Commission found that Israeli forces conducted more than 6,000 air strikes during Operation Protective Edge, firing approximately 50,000 tank and artillery shells and killing 1,462 Palestinian civilians - a third of whom were children..$^{98}$ In addition to the civilian casualties, there was enormous destruction of civilian infrastructure, including seventy-three medical facilities and many ambulances. ${ }^{99}$

Notably, the report did not look specifically into the attack on Al-Shifa Hospital; rather, the Commission examined several incidents, "including attacks on shelters, hospitals and critical infrastructure, in which artillery was used". ${ }^{100}$ It found that the use of "weapons with wide-area effects" against "targets in the vicinity of specifically protected objects (such as medical facilities and shelters)" could violate the principle of distinction. ${ }^{101}$ The report added that "depending on the circumstances, indiscriminate attacks may qualify as a direct attack against civilians, and may therefore amount to a war crime". ${ }^{102}$ Further, the Commission found that Israeli

political and military leadership did not change its course of action, despite considerable information regarding the massive degree of death and destruction in Gaza, [which] raises questions about potential violations of International Humanitarian Law by these officials, which may amount to war crimes. ${ }^{103}$

In particular, the Commission took issue with the indiscriminate nature of many of Israel's attacks on civilian infrastructure. ${ }^{104}$ The report called on all parties to respect IHL, especially the principles of distinction and proportionality. In not specifically reporting on findings for each hospital that was attacked, the Commission may have tried to balance the investigation and avoid individual scapegoating, but ultimately may have limited the strength of the evidence.

96 B'Tselem, Whitewash Protocol: The So-Called Investigation of Operation Protective Edge, September 2016, available at: www.btselem.org/publications/summaries/201609_whitewash_protocol.

97 Human Rights Council, above note 85, p. 19.

98 Ibid., p. 6.

99 Ibid.

100 Ibid., p. 6.

101 Ibid., p. 7.

102 Ibid., p. 12.

103 Ibid., p. 20.

104 Ibid., p. 12. 
Following the Commission's report, Human Rights Watch called for the International Criminal Court (ICC) to open a formal investigation into whether war crimes had been committed by either party during the conflict. ${ }^{105}$ On 16 January 2015, the Office of the Prosecutor at the ICC opened a preliminary examination of the situation, in order to establish whether the Rome Statute criteria for opening an investigation were met. ${ }^{106}$ Israel had previously rebuffed efforts by the ICC to investigate events in the Israeli-Palestinian conflict.

The ICC can only investigate alleged crimes in countries that have ratified the Rome Statute, or in a country that accepts the Court's jurisdiction, or if a particular armed conflict or country situation is referred to the Court by the UN Security Council for further investigation. ${ }^{107}$ Although Israel has not ratified the Rome Statute, Palestine ratified the Statute in April 2015 and gave the Court a mandate back to June 2014. ${ }^{108}$ On 20 December 2019, The ICC's chief prosecutor, Fatou Bensouda, concluded the preliminary examination and found that all the statutory criteria under the Rome Statute for the opening of an investigation had been met, so a formal investigation could be opened. ${ }^{109}$ On 30 April 2020, Bensouda reaffirmed her position that the ICC has jurisdiction over the Occupied Palestinian Territory, and requested Pre-Trial Chamber I to rule on this decision. ${ }^{110}$ On 5 February 2021, Pre-Trial Chamber I decided, by majority, that the Court's territorial jurisdiction extends to the territories occupied by Israel since 1967 - namely Gaza and the West Bank, including East Jerusalem. ${ }^{111}$ This decision marks an important step towards achieving international criminal accountability for crimes committed against Palestinians.

\section{Discussion}

Calls from international civil society members such as Human Rights Watch and MSF to investigate potential war crimes, and the force of the UN Commission of Inquiry, may have influenced the ICC prosecutor and the Pre-Trial Chamber's incredibly important decision to find jurisdiction over grave crimes committed in Palestine. As Fatou Bensouda announced, her decision marks a "long overdue step to move the process forward towards an investigation, after nearly five long

105 Human Rights Watch, "Palestine: ICC Should Open Formal Probe", 5 June 2016, available at: www.hrw. org/news/2016/06/05/palestine-icc-should-open-formal-probe.

106 ICC, "The Prosecutor of the International Criminal Court, Fatou Bensouda, Opens a Preliminary Examination of the Situation in Palestine", 16 January 2015, available at: www.icc-cpi.int/pages/item. aspx?name=pr1083.

107 ICC, "How the Court Works: Jurisdiction", available at: www.icc-cpi.int/about/how-the-court-works.

108 ICC, "Palestine Declares Acceptance of ICC Jurisdiction since 13 June 2014", press release, 5 January 2015, available at: $w w w . i c c-c p i . i n t / P a g e s / i t e m . a s p x ? n a m e=p r 1080 \& l n=e n$.

109 ICC, above note 106.

110 ICC, Situation in the State of Palestine: Prosecution Response to the Observations of Amici Curiae, Legal Representatives of Victims, and States, 30 April 2020, available at: www.icc-cpi.int/CourtRecords/ CR2020_01746.PDF.

111 ICC, "ICC Pre-Trial Chamber I Issues Its Decision on the Prosecutor's Request Related to Territorial Jurisdiction over Palestine”, press release, 5 February 2021, available at: www.icc-cpi.int/Pages/item. aspx?name=pr1566. 
and difficult years of preliminary examination". ${ }^{112}$ However, at the time of writing, it is unclear whether or not the attacks on Al-Shifa Hospital will be included in the prosecutor's indictment.

\section{Kunduz Trauma Centre, Afghanistan}

On 3 October 2015, US forces carried out an aerial bombardment of a trauma hospital operated by MSF in Kunduz, Afghanistan. In the fall of 2015, Taliban forces attempted to seize the city of Kunduz, which was then controlled by Afghan security forces. ${ }^{113}$ This was the first time since 2001 that the Taliban had taken control of a major city in Afghanistan. On 29 September 2015, Afghan forces, supported by US Forces Afghanistan, began a counter-attack. Four days later, US troops conducted a combat operation that struck the Kunduz Trauma Centre.

MSF opened the Kunduz Trauma Centre in 2011 as the only trauma facility in northeast Afghanistan. ${ }^{114}$ The facility provided free, high-quality care to patients, including those suffering from conflict-related injuries such as gunshots or bomb blasts. ${ }^{15}$ In the five years that it was operational, the trauma centre provided emergency care to 68,000 patients. ${ }^{116}$ A 2015 study determined that the centre had played a critical role in the region, saving 154,250 disability-adjusted life years in total through its operative care. ${ }^{117}$

Since the establishment of the Kunduz Trauma Centre, the Afghan government and relevant armed opposition groups had agreed to respect the neutrality of the medical facility. ${ }^{118}$ Per the agreement, all parties to the conflict would follow specific rules of IHL, including protection for medical patients and staff. Specifically, the agreement guaranteed that all wounded and sick patients would be treated without discrimination and that there would be no weapons inside the facility. In turn, MSF would comply with its ethical obligation to ensure that all people were treated regardless of their political or religious affiliation, and the facility would not be used for any military activities.

The Kunduz Trauma Centre treated both civilian and military patients, including Afghan government and police forces and Taliban fighters. ${ }^{119}$ Until

112 ICC, "Statement of ICC Prosecutor, Fatou Bensouda, on the Conclusion of the Preliminary Examination of the Situation in Palestine, and Seeking a Ruling on the Scope of the Court's Territorial Jurisdiction", 20 December 2019, available at: www.icc-cpi.int/Pages/item.aspx?name=20191220-otp-statement-palestine.

113 MSF, Initial MSF Internal Review: Attack on Kunduz Trauma Centre, Afghanistan, November 2015, p. 4, available at: https://reliefweb.int/sites/reliefweb.int/files/resources/Review\%20final\%20041115.pdf.

114 Ibid., p. 2.

115 Ibid.

116 Ibid.

117 Miguel Trelles et al., "Averted Health Burden over 4 Years at Médecins Sans Frontières (MSF) Trauma Centre in Kunduz, Afghanistan, Prior to its Closure in 2015”, Surgery, Vol. 160, No. 5, 2016, available at: https://doi.org/10.1016/j.surg.2016.05.024.

118 MSF, above note 113, p. 3.

119 Geoffrey Corn and Andrew Culliver, "Wounded Combatants, Military Medical Personnel, and the Dilemma of Collateral Risk", Georgia Journal of International and Comparative Law, Vol. 45, No. 3, 2017, p. 449, available at: https://digitalcommons.law.uga.edu/gjicl/vol45/iss3/2. 
September 2015, the centre had treated mostly government forces; then, as fighting intensified in Kunduz, the centre began to see an influx of wounded Taliban forces. ${ }^{120}$ By late September 2015, approximately half of the patients treated at the facility were wounded Taliban fighters. ${ }^{121}$ On 1 October 2015, a US government official sent a message to MSF inquiring as to whether a "large number of Taliban were "holed up" in the Kunduz Trauma Centre or in other MSF facilities in Afghanistan. ${ }^{122}$ MSF responded that it treated wounded Taliban fighters per the terms of medical neutrality in the hospital's mandate. In response, the US military liaison recommended that all staff stay within the GPS coordinates of the hospital.

On 29 September 2015, MSF reaffirmed its coordinates and sent them via email to the US Department of Defense (DoD), the Afghan Ministry of the Interior and Defence, and the US Army in Kabul. DoD officials confirmed their receipt of the coordinates and assured MSF that they had been sent to the appropriate parties. ${ }^{123}$ After the attack, the DoD reaffirmed that "multiple individuals at all levels of command were notified of the MSF Trauma Center's location via MSF or through U.S. chain-of-command". ${ }^{24}$

On the night of 3 October 2015, US air strikes hit and destroyed the main hospital. MSF later reported that the first room to be hit was the intensive care unit, where staff were caring for a number of immobile patients, including two children. ${ }^{125}$ Of the 105 patients being treated at the trauma centre, approximately twenty were wounded Taliban fighters. ${ }^{126}$ Meanwhile, a propeller plane shot doctors and medical staff as they tried to flee the main building, including a wheelchair-bound man who died of shrapnel injuries. The DoD and MSF reports conflicted in terms of the number of casualties and injuries. ${ }^{127}$

\section{Investigations and outcomes}

In the days following the attack, the US military justified its actions by claiming that its forces had "come under fire in the vicinity of the hospital". ${ }^{128}$ It later retracted this statement. Afghan officials similarly presumed that the air strike was targeted

120 MSF, above note 113 , p. 3 .

121 Ibid.

122 Ibid., p. 5.

123 Ibid.

124 US Central Command, Summary of the Airstrike on the MSF Trauma Center in Kunduz, Afghanistan on October 3, 2015: Investigation and Follow-On Actions 1, 29 April 2016, p. 27.

125 MSF, above note 113 , p. 9.

126 Ibid., p. 7.

127 "Use of Force and Arms Control: U.S. Department of Defense Releases Report of Investigation Finding that October 2015 Air Strike on Doctors Without Borders Hospital in Kunduz, Afghanistan, Was Not a War Crime", American Journal of International Law, Vol. 110, No. 3, 2016, p. 579; MSF, above note 113 , p. 9.

128 Alissa J. Rubin, “Airstrike Hits Doctors Without Borders Hospital in Afghanistan”, New York Times, 3 October 2015, available at: www.nytimes.com/2015/10/04/world/asia/afghanistan-bombing-hospitaldoctors-without-borders-kunduz.html. 
at Taliban fighters hiding in the hospital. ${ }^{129}$ Soon thereafter, MSF launched an internal investigation to determine "whether [the] hospital lost its protected status in the eyes of the military forces engaged in the attack - and if so, why". ${ }^{130}$ MSF concluded that the attack was deliberate and that the US knew it was targeting the trauma centre. The organization came to this conclusion based on information it had obtained indicating that the US knew Taliban fighters were nearby and believed that they were present in the facility. Based on its initial internal review, MSF concluded that hospital staff were in full control of the facility before and after the attack and that there were "no armed combatants within the hospital compound" and no evidence of "fighting from or in the direct vicinity of the trauma centre". ${ }^{131}$ MSF called for an independent investigation into the incident, referring to it as "not just an attack on our hospital, [but] an attack on the Geneva Conventions". 132

Soon thereafter, the US commander at the time of the strike, General John Campbell, launched an investigation to determine "the cause of the incident and whether the use of force complied with the law of armed conflict and the applicable rules of engagement". ${ }^{133}$ Campbell appointed over a dozen "subject matter experts" to the investigatory team, and the investigation lasted over five months. ${ }^{134}$ In its 726 -page report, the team concluded that the attack did not constitute a war crime. Although the team recognized that the attack violated the applicable IHL rules of engagement, it found that the United States was unaware that it was striking a medical facility, and therefore none of the individuals involved should be liable for war crimes. ${ }^{135}$ The United States did admit that around the time of the attack it was aware that Taliban insurgents had taken over parts of the city of Kunduz, and admitted that its goal was to "retake the city". ${ }^{136}$ The report concluded that while the United States had received the official coordinates of the trauma centre and had entered them into a "no strike list" database, the aircrew did not have access to the database at the time of the strike due to a critical communications systems failure. As a result, the aircrew mistook the facility for a lawful military target. ${ }^{137}$

While MSF claims that there were two MSF flags in full view on the roof of the hospital and one at the entrance of the building, the US report claimed that the facility did not have an "internationally recognized symbol to identify it as a medical

129 Nick Turse, "Why Bombing the Kunduz Hospital Was Probably a War Crime", The Intercept, 6 October 2015, available at: https://theintercept.com/2015/10/06/why-bombing-kunduz-hospital-was-probably-awar-crime/.

130 MSF, above note 113 , p. 9.

131 Ibid.

132 Ibid.

133 "Use of Force and Arms Control", above note 127, p. 579.

134 Ibid., p. 580.

135 Ibid.

136 Ibid.

137 US Central Command, "U.S. Central Command Releases U.S. Forces-Afghanistan Investigation into Airstrike on Doctors Without Borders Trauma Center in Kunduz, Afghanistan", press release, 29 April 2016, available at: www.centcom.mil/MEDIA/PRESS-RELEASES/Press-Release-View/Article/904574/ april-29-centcom-releases-investigation-into-airstrike-on-doctors-without-borde/. 
facility, such as the Red Cross or Red Crescent that was readily visible to the aircrew at night". ${ }^{138}$ Therefore, the report concluded, the personnel involved did not know they were striking a medical facility.

The US report dismissed MSF's contention that US forces had committed a war crime by intentionally striking the hospital, and instead focused on the systems errors that caused the attack. The US report also confirmed that "no individuals there were committing hostile acts", ${ }^{139}$ and that US forces failed to comply with the rules of engagement by not determining that the Kunduz Trauma Centre was a lawful military objective before attacking. ${ }^{140}$ Additionally, the report found that the United States did not follow the Pentagon's Law of War Manual, which reinforces the IHL principle of proportionality, because the aircrew "failed to take precautions to reduce the risk of harm to individuals they could not positively identify as combatants". ${ }^{141}$ Nevertheless, the United States concluded that the aerial bombardment did not amount to a war crime because that legal determination is "typically reserved for intentional acts". ${ }^{142}$ Accordingly, none of the US military members involved were referred for criminal prosecution.

Brigadier-General Shane Reeves, deputy head of the Department of Law at West Point, confirmed in an interview for this article that the US investigation followed standard protocol. ${ }^{143}$ In addition to the US national investigation, the NATO and Afghan-partnered Combined Civilian Casualty Assessment Team also conducted an investigation. ${ }^{144}$ The findings of both reports were generally consistent, though there were differences on the number of casualties. Since the full reports are not publicly available, neither a full comparison of the reports nor a deeper assessment of how the investigations were conducted is possible at the time of writing. Brigadier-General Reeves explained that the US military wishes to be transparent in its commitment to investigating alleged violations of IHL, which is why it made its findings public. He also explained that the internal investigation was not in response to external complaints, but was a routine matter. DoD Directive 2311.01(e) provides that "all reportable incidents committed by or against U.S. personnel, enemy persons, or any other individual [should be] reported promptly, investigated thoroughly and, where appropriate,

138 ICRC, "Afghanistan, Attack on Kunduz Trauma Centre”, How Does Law Protect in War?, available at: https://casebook.icrc.org/case-study/afghanistan-attack-kunduz-trauma-centre. See also GC I, Art. 42; GC IV, Art. 18; E. Mikos-Skuza, above note 80, p. 207 (international law requires military hospitals to be marked with a protective emblem, such as the red cross or red crescent; civilian hospitals are also required to mark themselves with protective emblems, but must first get State authorization and recognition); "Use of Force and Arms Control", above note 127, p. 579.

139 "Use of Force and Arms Control", above note 127, p. 582.

140 Ibid., p. 584.

141 Ibid., p. 585.

142 Ibid.

143 Telephone interview with Shane Reeves, Deputy Head of the Department of Law at West Point, New York, March 2019. These views are Brigadier-General Reeves's alone and do not reflect those of the DoD, US Army or United States Military Academy.

144 US Department of Defense, "Department of Defense Press Briefing by General Campbell via teleconference from Afghanistan", 25 November 2015, available at: www.defense.gov/Newsroom/ Transcripts/Transcript/Article/631359/department-of-defense-press-briefing-by-general-campbell-viateleconference-fro/. 
remedied by corrective action". ${ }^{145}$ Moreover, the DoD Law of War Manual sets out the State's duties and obligations under IHL. However, since the United States is not a party to AP I, it has not consented to any investigations of alleged violations of IHL made by other States Parties.

\section{Discussion}

Unlike in the Quynh Lap case, the United States could not claim that the attack on the Kunduz Trauma Centre was due to a misidentification as it had received the coordinates of the facility before the air strike. The Kunduz case is significant because it received considerable public attention, which prompted multiple investigations. After the US findings were released, the non-governmental organization (NGO) community, including MSF and Human Rights Watch, openly questioned the conclusion that no war crime had occurred (because the attack was considered a systems failure and not an intentional attack) and called for further investigations and public access to the reports. Again, since the full reports are not publicly available and no comparable public reports exist, neither a full comparison of the reports nor a deeper assessment of how the investigations were conducted is possible.

The Kunduz case also brings to light the tensions that can arise when determining if attacks on hospitals should amount to war crimes even if they are not deliberate. MSF's president articulated this tension:

The threshold that must be crossed for this deadly incident to amount to a grave breach of International Humanitarian Law is not whether it was intentional or not. ... [A]rmed groups cannot escape their responsibilities on the battlefield simply by ruling out the intent to attack a protected structure such as a hospital. ${ }^{146}$

While the Rome Statute of the ICC only attaches criminal liability for war crimes if they are "intentional", some legal scholars argue that customary international law (CIL) and international case law do not follow this standard. ${ }^{147}$ CIL interprets the term "intentional" in the Statute to also include a lower "recklessness" standard. ${ }^{148}$ Using this standard, the action taken by the United States in Kunduz could be deemed reckless: 211 artillery shells were unleashed on a hospital without any hostile threat being confirmed. The ICC's Office of the Prosecutor stated that "[a]lleged crimes committed in Kunduz during the SeptemberOctober 2015 events will be further examined by the office", and on 5 March 2020, the Appeals Chamber unanimously voted to commence an investigation into alleged crimes committed on the territory of Afghanistan since 1 May 2003. ${ }^{149}$

145 DoD Directive 2311.01E, “DoD Law of War Program”, 9 May 2006, Sec. 4.4.

146 "Use of Force and Arms Control", above note 127, p. 586.

147 ICTY, Prosecutor v. Delalić case, Case No. IT-96-21-T, Judgment (Trial Chamber II), 16 November 1998, paras $437,439$.

148 "Use of Force and Arms Control", above note 127, p. 586.

149 ICC, Judgment on the Appeal against the Decision on the Authorisation of an Investigation into the Situation in the Islamic Republic of Afghanistan, Case No. ICC-02/17-138, 5 March 2020, available at: www.icc-cpi.int/Pages/record.aspx?docNo=ICC-02/17-138. 
This case highlights the urgent need for recognition of the practical rules under which hospitals operate in armed conflicts. Although the United States did not justify its attack based on misuse, the Geneva Conventions and CIL are clear that wounded fighters must be treated without discrimination and that a hospital does not lose its protected status for fulfilling its obligation to care for wounded fighters as it does for all other patients.

\section{Conclusion}

In this article, we set out to understand how IHL protects hospitals in armed conflict. In each of the four case studies, we examined the weaknesses and strengths of IHL and the subsequent investigation(s), if any, that were conducted to determine if IHL had been violated. The case studies reveal three actions that could help promote greater accountability for violations of IHL.

First, independent, robust and transparent investigations are necessary to convict or exonerate alleged perpetrators of attacks on hospitals in armed conflict. As we explained in the cases of Al-Shifa and Kunduz, an unbiased understanding of the events and any potential criminal accountability for individual actors is impossible without complete and transparent investigations. While accountability was lacking in both cases, thorough investigations into violations of IHL can serve to clarify the law and strengthen the expectation that States should formally investigate alleged attacks on hospitals. As the ICRC and Geneva Academy's Guidelines on Investigating Violations of International Humanitarian Law explain:

Taking steps to determine whether a violation of international humanitarian law has occurred, and if so, to remedy it, is the primary responsibility of States. It should be noted, however, that when accountability failures occur or are thought to have occurred, international or regional bodies and processes (such as fact-finding missions, commissions of inquiry, tribunals), may be triggered to examine events and recommend or require action. ${ }^{150}$

While States must fulfil their obligation to investigate possible violations of IHL, investigations by independent NGOs are also beneficial. For example, media and civil society organizations, such as Amnesty International and the UC Berkeley Human Rights Center, are using open-source techniques in an effort to document and investigate violations of IHL. In October 2019, the New York Times published an article attributing hospital bombings in Syria to Russian forces based largely on an open-source investigation conducted by the newspaper's Visual Investigations team. The team's findings added to the growing body of

150 Noam Lubell, Jelena Pejic and Claire Simmons, Guidelines on Investigating Violations of International Humanitarian Law: Law, Policy, and Good Practice, Geneva Academy and ICRC, 16 September 2019, p. 6, available at: www.geneva-academy.ch/joomlatools-files/docman-files/Guidelines\%20on\%20Investigating\% 20Violations\%20of\%20IHL.pdf. 
proof that Russia may have recklessly or intentionally bombed hospitals in the Syrian conflict. ${ }^{151}$

Second, civil society is vital to ensuring that violations of IHL are brought to the attention of the public and potentially investigated. When State or formal legal mechanisms are lacking, public "naming and shaming" may be the only available means of obtaining some semblance of accountability. As such, civil society acts as the custodian of IHL by ensuring that the plight of victims and their communities is not ignored and forgotten. Civil society organizations may uphold IHL principles by articulating the immediate and long-term benefits of respecting IHL and by promoting more compelling non-legal arguments, particularly at the policy level. ${ }^{152}$

Finally, criminal prosecutions for those responsible for violations of IHL are necessary to strengthen respect for the laws of war. Those who violate the law should be held accountable, but as we have seen, attacks on hospitals often go unpunished. One important way to achieve accountability for violations of IHL is through criminal prosecutions. The fact that Galić in Bosnia and the Israeli military justified their attacks using language from IHL instruments itself implies an acceptance of these legal instruments. Thus, we can conclude that the frequent violations of IHL do not signal a deterioration of the legal principles, since in almost every case study, the ensuing public condemnation of the attacks on hospitals promoted the integrity of IHL. In sum, existing IHL rules can protect hospitals in armed conflict but what are lacking, in addition to greater State adherence to the laws of war, are more robust mechanisms for investigating and prosecuting the individuals responsible for violations of IHL.

Investigatory mechanisms should be strengthened both internationally and nationally. Although the laws of war require States to "examine" and "investigate" alleged violations, our case studies show that actual investigations are often not uniform or are only undertaken at the discretion of States. To ensure that all breaches of IHL are investigated impartially, States should formally recognize the importance of independent commissions of inquiry. Many States have done this by adhering to Article 90 of AP I, which recognizes the competence of the IHFFC to investigate allegations by another party, even though the IHFFC is an imperfect mechanism. Otherwise, the international community should continue to promote other fact-finding or reporting mechanisms to investigate alleged breaches of IHL. While the UN Security Council, through its Resolution 2286, urged States to adopt independent impartial investigations within their domestic jurisdictions, there is little evidence that it has been effective. As several legal scholars have suggested, the $\mathrm{UN}$ must work towards resolving the issues found by commissions of inquiry and other independent monitoring and reporting mechanisms. ${ }^{153}$

151 Evan Hill and Christiaan Triebert, "12 Hours. 4 Syrian Hospitals Bombed. One Culprit: Russia”, New York Times, 13 October 2019, available at: www.nytimes.com/2019/10/13/world/middleeast/russia-bombingsyrian-hospitals.html.

152 ICRC, "Changing the Narrative on IHL", panel at the Conference on "Generating Respect for the Law", 2 October 2017, available at: www.icrc.org/en/document/changing-narrative-ihl.

153 Ginette Petitpas Taylor et al., "Protecting Health Care in Armed Conflict: Action Towards Accountability", The Lancet, Vol. 391, No. 10129, 14 April 2018, available at: www.thelancet.com/ journals/lancet/article/PIIS0140-6736(18)30610-X/fulltext. 
While they are robust, the laws of war can and should be strengthened. First, IHL must adapt to the changing landscape of armed conflicts. Today, armed conflicts often take place in cities and densely populated environments. ${ }^{154}$ As a result, medical facilities and personnel may be in close proximity to legitimate military targets. And while the 2016 Commentary on Geneva Convention I regards "the placing of a medical unit in proximity to a military objective with the intention of shielding it from the enemy's military operations" as an "act harmful to the enemy", ${ }^{155}$ this opinion, while cautionary, should not be used as a justification for attacking medical facilities when such units may have no other option but to operate near military sites. Even if hospitals are misused and become legitimate military targets (which could have been the case in Kunduz if the hospital truly did shield armed Taliban fighters), the IHL principle of precaution still requires parties to take all feasible precautions to minimize civilian harm, and the principle of proportionality may mean that an attack on a hospital in a densely populated area is not justified if civilian casualties outweigh the military advantage. ${ }^{156}$

Second, the international community should evaluate the subjective intent of State actors whenever they try to justify their attacks on the basis of misuse. As our case studies illustrate, perpetrators of attacks on hospitals often attempt to justify their orders by claiming hospital misuse or unintentional targeting - but while there was evidence that could have suggested misuse in the Bosnia and Afghanistan cases, there was also evidence to the contrary. The requirement of warning hospitals before attacking is meant to evaluate the subjective intent of the act harmful to the enemy. In the above case studies, the attackers did not confirm whether the hospital misuse was intentional, or send the requisite warnings before attacking. The international community should therefore investigate thoroughly any instances where hospital misuse is given as a justification for attacks, especially when there is no evidence of intent. Conversely, there needs to be more clarity surrounding the intentionality of the attack. Individual criminal liability before the ICC requires a deliberate, knowing attack, but the Geneva Conventions do not. IHL attributes responsibility to States party to armed conflicts while international criminal law attributes responsibility to individual perpetrators. We recommend that in all instances, parties investigating attacks on health care closely scrutinize the intention of the alleged perpetrators. Focusing on the intentionality of the parties involved will certainly strengthen IHL and the goal of protecting health care overall. It is important to determine the intentionality behind alleged attacks; because little is known about how military decision-makers verify the activities taking place within the confines of a health-care facility, robust independent investigations - undertaken with due

154 Nicholas W. Mull, “A Critique of the ICRC's Updated Commentary to the First Geneva Convention: Arming Medical Personnel and the Loss of Protected Status", Georgia Journal of International and Comparative Law, Vol. 45, No. 3, 2017, p. 504.

155 ICRC Commentary on GC I, above note 12, Art. 21, para. 1842.

156 N. W. Mull, above note 154, p. 504. 
consideration of national security implications - must be conducted to shed light on how these decisions are made and later justified.

Finally, since criminal prosecutions of alleged IHL offenders are infrequent and generally take years to complete, the international community should utilize other accountability mechanisms, such as launching public advocacy campaigns to end impunity for offenders. While attacks on hospitals are rarely prosecuted, the laws protecting hospitals are some of the strongest in IHL and should serve to incentivize prosecutors and civil society members to continue to carry out investigations and to hold perpetrators accountable.

As the scholar Leonard Rubenstein puts it: "It's too simplistic to say [IHL] has failed. Everything is a step ... [but] it doesn't mean you throw in the towel. [We must] put pressure on governments to [uphold IHL]." ${ }^{157}$ 